\title{
Treatment of Inflammatory Bowel Disease: Is your Patient at Risk of Non-Adherence?
}

\author{
Tratamento da Doença Inflamatória Intestinal: Estará o seu Doente em \\ Risco de Não Adesão?
}

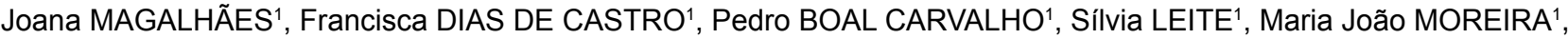 \\ José COTTER ${ }^{1,2,3}$ \\ Acta Med Port 2014 Sep-Oct;27(5):576-580
}

ABSTRACT

Introduction: Adherence to therapy is a key factor when analyzing the efficacy of a treatment in clinical practice. The aim of our study was to assess the frequency of non-adherence to treatment among patients with inflammatory bowel disease and evaluate which factors could be related.

Material and Methods: One hundred thirty eight consecutive inflammatory bowel disease outpatients $(55.8 \%$ with Crohn's disease and $44.2 \%$ with Ulcerative Colitis) filled in an anonymous questionnaire, which included information about demography, duration of the disease, specific therapy for inflammatory bowel disease, and data possibly related to extent of non-adherence to treatment. Statistics were performed with SPSS v.18.0. Categorical variables were compared with Fisher's exact test. A $p$ value $<0.05$ was considered statistically significant. Significant variables in univariate analysis were included in the logistic regression analysis.

Results: Overall non-adherence was reported by $29.7 \%$ of patients. $70.7 \%$ of them reported unintentional non-adherence and $51.2 \%$ forgot at least one dose per week. Non-adherence was statistically associated with: short disease duration $(p<0.001)$; young age $(p=0.001)$; topical aminosalicylates $(p=0.005)$; the perception that medical therapy isn't effective enough $(p=0.007)$ and high educational level $(p=0.011)$. In a logistic regression analysis, topical aminosalicylates use $(p=0.004)$, short disease duration $(p=0.006)$ and young age $(p=0.027)$ were identified as significant predictors of non-adherence.

Discussion: Young patients, patients with short disease duration and under topical aminosalicyates presented a higher risk for nonadherence to treatment.

Conclusions: Gastroenterologist's attention should be focused on the identification of risk factors potentially involved in non-adherence to therapy and in the promotion of measures to improve it.

Keywords: Inflammatory Bowel Disease; Crohn Disease; Colitis, Ulcerative; Patient Compliance; Risk Factors; Treatment Refusal.

\section{RESUMO}

Introdução: A adesão à terapêutica é um aspecto chave para a eficácia da terapêutica. O objectivo deste estudo foi avaliar a frequência e factores de risco associados à não adesão à terapêutica na doença inflamatória intestinal.

Material e Métodos: Cento e trinta e oito doentes com doença inflamatória intestinal $(55,8 \%$ com Doença de Crohn e $44,2 \%$ com Colite Ulcerosa) preencheram um questionário sobre dados referentes à sua doença e comportamentos de não adesão ao tratamento. A análise estatística foi realizada com SPSS 18, a associação entre variáveis categóricas foi determinada através do teste exato de Fisher. Variáveis estatisticamente significativas na análise univariada foram incluídas no modelo de regressão logística.

Resultados: A não-adesão à terapêutica foi registada em $29,7 \%$ dos doentes. Em $70,7 \%$ dos casos foram referidos comportamentos não intencionais e 51,2\% esqueceram pelo menos uma dose por semana. A não-adesão à terapêutica apresentou uma associação significativa com o diagnóstico recente da doença $(p<0,001)$, idade jovem $(p=0,001)$, aminossalicilatos tópicos $(p=0,005)$, percepção individual de baixa eficácia da terapêutica $(p=0,007)$ e uma escolaridade elevada $(p=0,011)$. No modelo de regressão logística os aminossalicilatos tópicos $(p=0,004)$, o diagnóstico recente da doença $(p=0,006)$ e a idade jovem $(p=0,027)$, foram identificados como preditores de não adesão à terapêutica.

Discussão: Doentes jovens, com diagnóstico recente e sob terapêutica com aminossalicilatos tópicos apresentaram um maior risco para comportamentos de não adesão.

Conclusões: A atenção dos gastrenterologistas deve focar-se na identificação dos fatores de risco envolvidos na não adesão e na promoção de medidas que contribuam para a diminuição da mesma.

Palavras-chave: Doença Inflamatória Intestinal; Doença de Crohn; Colite Ulcerosa; Cooperação do Doente; Factores de Risco; Recusa do Doente ao Tratamento.

\section{INTRODUCTION}

Adherence to therapy is a key aspect in determining the efficacy of a given drug in the clinical practice. Adherence may be defined as the extent to which patient's behavior (in terms of taking medication, following a diet, modifying habits, or attending clinics) coincides with medical or health advice. ${ }^{1}$

Adherence to treatment is generally optimal in short term diseases, which are characterized by a predictable course and

a rapid resolution after introduction of therapeutic, on the other hand, chronic diseases with an unpredictable course, long periods of low activity and the need for lifelong medication are frequently related with non-adherence behaviors. ${ }^{2}$

Inflammatory bowel diseases (IBD), which encompasses ulcerative colitis (UC) and Crohn's disease (CD), are chronic diseases with a relapsing-remitting disease course requiring

1. Serviço de Gastrenterologia. Centro Hospitalar do Alto Ave. Guimarães. Portugal.

2. Life and Health Sciences Research Institute. School of Health Sciences. University of Minho. Braga. Portugal.

3. ICVS/3B's PT Government Associate Laboratory. Braga/Guimarães. Portugal.

Recebido: 20 de Dezembro de 2013 - Aceite: 16 de Junho de 2014 | Copyright @ Ordem dos Médicos 2014 
lifelong treatment. These diseases represent a high risk situation for non-adherence: a chronic illness, affecting young patients, with an unpredictable course, with naturallyoccurring long inactive periods, and sometimes managed by non-convenient or difficult-to-follow therapies. ${ }^{3-5}$ On the other hand, poor adherence may result in more frequent relapses, a disabling disease course, increases in the frequency of hospital admissions and an overall rise in healthcare costs. ${ }^{6,7}$ With these outcomes, it is now even more important to understand the factors involved with non-adherence behavior and identify which patients are at highest risk, so that intervention can occur early.

The aim of our study was to evaluate the frequency of nonadherence to the treatment among ambulatory patients with IBD and to study which factors could influence it.

\section{MATERIAL AND METHODS}

Patients with the diagnosis of IBD, followed up in the Gastroenterology Department at Centro Hospitalar do Alto Ave, Guimarães, were prospectively interviewed during an outpatient specialist visit using a questionnaire.

The patients were informed about adherence problems and the study's character. They were assured that the responses in no way will influence their further treatment options and those who agreed with participation were enrolled and signed the informed consent.

A written interview was done, anonymously and without the presence of any of the treating physicians. Some patients with difficulties to understand the questionnaire had help from a gastroenterology nurse. We excluded patients seen for the first time, in urgent context, treated with monotherapy with biological agents and those unable to fill up the questionnaire.

The questionnaire included 23 questions regarding: 1) demographic data: age, gender, studies and working status, 2) data on the disease character: type of IBD, year of diagnosis, number of hospital admissions, and number of IBD-related surgical procedures, 3) data on their treatment: drugs and type (oral vs. topical), 4) adherence to treatment 5 ) how often the medication was forgotten (rarely, sometimes, often, very often), 6) number of doses usually forgotten every week during the year preceding the survey, and reason for forgetting them, 7) smoking habits, and 8) complementary and alternative medicine (CAM) use.

In our study, patients were considered to be non-adherent if they forgot at least a dose a week, often or very often, during the last 12 months.

\section{Statistical Methods}

Using the Gpower ${ }^{\circledR}$ software and taken into consideration the statistical tests employed, we determined the minimum sample size to be eighty patients.

Data were analyzed with SPSS 18.0. For continuous variables, mean and standard deviation were calculated. For categorical variables, percentages were provided. Categorical variables were compared with Chi-square test, and in cases where the premises of this test were not met (no more than $20 \%$ of cells with expected frequencies less than 5 ) was used the Fisher's exact test. A $p$ value $<0.05$ was considered statistically significant. Binary logistic regression was used to determine the association between demographic variables and

Table 1 - Clinical and demographic characteristics of patients who complete the questionnaire

\begin{tabular}{|c|c|c|}
\hline & CD & CU \\
\hline Number of patients, $n$ & 77 & 61 \\
\hline Gender, $n(\%)$ & 47 (61) female & $34(55.7)$ female \\
\hline Duration of IBD, mean $\pm \mathbf{S D}^{\star}(\min -\max )$ & $4.3 \pm 3.8(1-18)$ years & $5.0 \pm 4.1(1-20)$ years \\
\hline$\leq 5$ years, $n(\%)$ & $57(74.0)$ & $38(62.3)$ \\
\hline$>5$ years, $n(\%)$ & $20(26.0)$ & $23(37.7)$ \\
\hline Age, mean $\pm \mathrm{SD}^{\star}(\min -\max )$ & $32.5 \pm 12.0(17-75)$ years & $37.3 \pm 12.8(16-68)$ years \\
\hline$\leq 30$ years, $n(\%)$ & $45(58.4)$ & $24(39.3)$ \\
\hline$>30$ years, $n(\%)$ & $32(41.8)$ & $37(60.7)$ \\
\hline \multicolumn{3}{|l|}{ Current medical therapy for IBD, $n(\%)$} \\
\hline Oral Aminosalicylates & $34(44.2)$ & $50(82.0)$ \\
\hline Topical Aminosalicylates & - & $23(37.7)$ \\
\hline Steroids & $7(9.1)$ & $1(1.6)$ \\
\hline Azathioprine & $45(58.4)$ & $21(34.4)$ \\
\hline Biological therapy & $12(15.6)$ & $6(9.8)$ \\
\hline IBD-related hospital admission $n(\%)$ & $53(68.8)$ & $24(39.3)$ \\
\hline IBD-related surgical procedure $n(\%)$ & $23(29.9)$ & - \\
\hline \multicolumn{3}{|l|}{ Education level $n(\%)$} \\
\hline Primary studies & $3(3.9)$ & $9(14.8)$ \\
\hline Lower secondary education & $23(29.9)$ & $15(24.6)$ \\
\hline Upper secondary education & $33(42.9)$ & $26(42.6)$ \\
\hline University studies & $18(23.4)$ & $11(18)$ \\
\hline Smoking habits, $n(\%)$ & $20(26)$ & $10(16.4)$ \\
\hline CAM use $^{\star \star}, n(\%)$ & $7(9.1)$ & $3(4.9)$ \\
\hline
\end{tabular}

${ }^{*}$ SD: standard deviation; ${ }^{*}$ CAM: complementary and alternative medicine 
disease characteristics and non-adherence. Each variable with $p<0.05$ identified in univariate association testing was included in the logistic regression analysis.

\section{RESULTS}

A total of 138 consecutive IBD patients were interviewed. The questionnaire was correctly filled up by $100 \%$ of patients, but two of them with nurse help. Main clinical characteristics of the study population are shown in Table 1.

In this sample, $29.7 \%(n=41)$ of the patients reported nonadherence to their treatment, 16 of those with UC and 25 of those with $C D$. As there was no apparent difference between the two diseases in terms of adherence, they were considered together in the subsequent analysis.

Involuntary non-adherence behavior (simple forgetfulness) was reported in $29(70.7 \%)$ patients. The voluntary non-adherence was observed in $12(29.3 \%)$ patients. The most common causes of voluntary non-adherence: too many/ unnecessary drugs in $7(17.1 \%)$ patients; being afraid of side effects in $4(9.8 \%)$ patients and complicated administration of topical aminosalicylates in $1(2.4 \%)$ patient. Twenty one $(51.2 \%)$ patients revealed a behavior of non-adherence at least one dose a week; $8(19,5 \%)$ patients forgot two doses a week; $9(22.0 \%)$ patients forgot three doses a week and $3(7.3 \%)$ patients were non-adherent four or more doses per week.

Non-adherence was statistically associated with: short disease duration $(p<0.001)$, young age $(p=0.001)$, therapy with topical aminosalicylates $(p=0.005)$, the perception that medical therapy isn't effective enough $(p=0.007)$ and high educational level ( $p=0.011$ ) (Table2). On the other hand, different factors such as gender $(p=1.000)$, disease type ( $p=0.458)$, smoker status $(p=1.000)$, occurrence of minor side effects $(p=0.635)$, use of alternative medicine ( $p=1.000)$, previous IBD-related admissions $(p=1.000)$, previous surgeries ( $p=0.619)$; unemployment status $(p=0.349$ ) and therapy (oral aminosalicylates $p=1.000$; azathioprine $p=0.854$; steroids $p=0.436$ ) did not correlate with the degree of adherence.

In a logistic regression analysis, the topical aminosalicylates use $(p=0.004)$, the short disease duration $(p=0.006)$ and young age $(p=0.027)$ were identified as significant predictors of non-adherence to treatment (Table 3 ).

\section{DISCUSSION}

The causes of medication non-adherence are complex, where the patient-doctor relationship, treatment regimen, and other disease-related factors play key roles. Non-adherence is significant whenever it determines a change in the therapeutic effect intended with the drug prescribed.

Clinical trials reporting efficacy and safety of treatment therapies available in the management of IBD have reported patient adherence rates of between $70 \%$ and $95 \% .{ }^{8,9}$ However, trials are an ideal situation, in which therapy supervision is more intense than usual. In real life treatment adherence is lower, with percentage of non-adherent patients ranging between $38 \%$ to $70 \% .^{3,9-13}$ In our work we found a lower percentage of non-adherent behavior $(29.7 \%)$, even so, a significant number of our patients are not benefiting from the full potential of their therapy. There is no gold standard method to measure adherence, but interview and questionnaire methods are most commonly used because they are easy to obtain and inexpensive. These questionnaires are susceptible to underrepresentation and tend to overestimate adherence, but they detect most non-adherent patients. ${ }^{14}$ Although we used a questionnaire to assess the medication-taking behavior, it was conducted according to general standards to increase valid responses (i.e., nonjudgmental questions were used and confidentiality was emphasized).

Differentiating voluntary non-adherence and involuntary non-adherence (simple forgetfulness) is useful to be able to define a strategy aiming a correction of the problem. Bermejo et $\mathrm{al}^{13}$ describe $66 \%$ of some involuntary non-adherence. The involuntary non-adherence that we report in our study is similar $(70.7 \%)$. In these patients is possible that adherence may be improved with different strategies, such as setting alarms on watches/mobile phones or traditional reminders (placing pills close to something they use daily, e.g. the toothpaste, breakfast table, glasses or contact lenses case, night-time beverage, etc. $){ }^{15}$ As in other studies, ${ }^{3,13,16}$ voluntary non-adherence was less frequent (29.3\%), but its significance greater, because it represents an active decision by the patient. Education of patients is a key to reverse this situation, because it may address unrealistic fears and associations the patient has with their medication.

Age seems to be an important factor, as younger patients tend to be less adherent than older patients. ${ }^{3,16}$ D'Inca et $\mathrm{al}^{16}$ reported that non-adherence was $43 \%$ in patients < 40 years old compared to $34 \%$ in those older than 40 years $(p=0.041)$. Diagnosis and disease duration shorter than 5 years was also associated with significantly worse adherence $(24 \%$ of the patients) than a longer-standing disease (15\% of the patients) in the same study. In the present study, both young age and short disease duration were also associated with higher nonadherence rates. This may be related to the fact that IBD primarily affects young individuals with greater personal and social goals, being busy at work, and having some degree of rebelliousness, but it may also be that a younger age is associated with a more recent diagnosis, with less experience with the burden of relapse. ${ }^{17}$

Our study found that topical therapy with enemas, suppositories or foams was significantly associated with non-adherence in univariate analysis $(p=0.005)$ and in logistic regression model ( $p=0.004)$. In this group of patients, the voluntary behavior (8 patients, $61.5 \%$ of nonadherent patients) was the main reason for non-adherence to treatment, and although only one patient refer the complicated administration of topical aminosalicylates as the main cause for this behavior, a significant number of this patients reported too many/unnecessary drugs (4 patients, $30.7 \%$ ) and being afraid of side effects (3 patients, 23.1\%). Previous studies have also reported that non-adherence to therapy might also be due not only to the drug formulation causing discomfort (difficulty in swallowing tablets or using enemas) but also to the side effects (pain or abdominal distension, difficulty in 
Table 2 - Predictive factors for non-adherence in patients with IBD (univariate analysis)

\begin{tabular}{|c|c|c|}
\hline & Non-adherent, $n(\%)$ & ${ }^{\mathrm{s} p} \boldsymbol{p}$ value \\
\hline $\begin{array}{l}\text { Type of disease } \\
\text { CD } \\
\text { UC }\end{array}$ & $\begin{array}{l}25(32.5) \\
16(26.2)\end{array}$ & 0.458 \\
\hline $\begin{array}{l}\text { Gender } \\
\text { Female } \\
\text { Male }\end{array}$ & $\begin{array}{l}24(29.6) \\
17(29.8)\end{array}$ & 1.000 \\
\hline $\begin{array}{l}\text { Age } \\
\quad \leq 30 \text { years } \\
\quad>30 \text { years }\end{array}$ & $\begin{array}{l}30(43.5) \\
11(15.9)\end{array}$ & 0.001 \\
\hline $\begin{array}{l}\text { Duration of IBD } \\
\quad \leq 5 \text { years } \\
>5 \text { years }\end{array}$ & $\begin{array}{c}38(40.0) \\
3(7.0)\end{array}$ & $<0.001$ \\
\hline $\begin{array}{l}\text { Educational level } \\
\text { Low/Medium } \\
\text { High }\end{array}$ & $\begin{array}{c}8(16) \\
33(37.5)\end{array}$ & 0.011 \\
\hline $\begin{array}{l}\text { Employment status } \\
\text { unemployed } \\
\text { employed }\end{array}$ & $\begin{array}{l}10(37.0) \\
30(27.3)\end{array}$ & 0.349 \\
\hline $\begin{array}{l}\text { IBD-related hospital admiss } \\
\text { Yes } \\
\text { No }\end{array}$ & $\begin{array}{l}23(29.9) \\
18(29.5)\end{array}$ & 1.000 \\
\hline $\begin{array}{l}\text { IBD-related surgical proced } \\
\text { Yes } \\
\text { No }\end{array}$ & $\begin{array}{c}8(34.8) \\
33(28.7)\end{array}$ & 0.619 \\
\hline $\begin{array}{l}\text { Individual perception of the } \\
\text { Significant improvement } \\
\text { Slight or no improvement }\end{array}$ & $\begin{array}{c}37(27.6) \\
4(100)\end{array}$ & 0.007 \\
\hline $\begin{array}{l}\text { Occurrence of minor side e } \\
\text { Yes } \\
\text { No }\end{array}$ & $\begin{array}{c}32(28.6) \\
9(34.6)\end{array}$ & 0.635 \\
\hline $\begin{array}{l}\text { CAM }^{\star \star} \text { use } \\
\text { Yes } \\
\text { No }\end{array}$ & $\begin{array}{c}3(30.0) \\
38(29.7)\end{array}$ & 1.000 \\
\hline $\begin{array}{l}\text { Smoking habits } \\
\text { Yes } \\
\text { No }\end{array}$ & $\begin{array}{c}9(30.0) \\
32(29.6)\end{array}$ & 1.000 \\
\hline $\begin{array}{l}\text { Topical Aminosalicylates } \\
\text { Yes } \\
\text { No }\end{array}$ & $\begin{array}{l}13(56.5) \\
28(24.3)\end{array}$ & 0.005 \\
\hline $\begin{array}{l}\text { Oral Aminosalicylates } \\
\text { Yes } \\
\text { No }\end{array}$ & $\begin{array}{l}25(29.8) \\
16(29.6)\end{array}$ & 1.000 \\
\hline $\begin{array}{l}\text { Steroids } \\
\text { Yes } \\
\text { No }\end{array}$ & $\begin{array}{c}1(12.5) \\
40(30.8)\end{array}$ & 0.436 \\
\hline $\begin{array}{l}\text { Azathioprine } \\
\text { Yes } \\
\text { No }\end{array}$ & $\begin{array}{l}19(28.8) \\
22(30.6)\end{array}$ & 0.854 \\
\hline
\end{tabular}

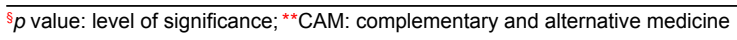

retaining enemas). ${ }^{17}$

In the present study, we did not find an association between the drug type (oral aminosalicylates $p=1.000$, steroids $p=$ 0.436 and azathioprine $p=0.854$ ) and medical adherence, It should be noted that our study assesses self-report of typical medication adherence, it does not directly assess adherence behavior in the context of a specific treatment as a pill count would. We also did not report the adherence data for AntiTNF monotherapy, as compliance therapy in these patients is closely monitored in our department.

A higher education level was associated with a nonadherent patient behavior in some, but not all studies. ${ }^{10,12,18-20}$
We found an association between high educational level and non-adherence to treatment $(p=0.011)$, but in logistic regression model this variable showed no predict ability on non-adherence to treatment.

As reported in this study a patient perception of benefits derived from therapy was associated with adherence to treatment in univariate analysis $(p=0.007)$, but without significant predictive value on logistic regression model. In the study of Shale et $\mathrm{al}^{18}$ perceiving medication as ineffective was also related to non-adherent behavior. Lack of knowledge of how the medication works and patients' beliefs may be at the origin of this behavior. Patients need to be informed, 
Table 3 - Predictive factors for non-adherence in patients with IBD (logistic regression)

\begin{tabular}{|c|c|c|c|}
\hline & ${ }^{s} p$ value & "OR & $95 \%{ }^{\S \S} \mathrm{Cl}$ \\
\hline Age & 0.027 & 0.31 & $0.11-0.88$ \\
\hline Duration of IBD & 0006 & 0.06 & $0.01-0.44$ \\
\hline Educational level & "Ins. & - & - \\
\hline Individual perception of the efficacy of therapy & "ITs. & - & - \\
\hline Topical Aminosalicylates & 0.004 & 5.28 & $1.68-16.5$ \\
\hline
\end{tabular}

motivated and skilled in the use of cognitive and behavioral CONCLUSION

self-regulation strategies if they are to cope effectively with the treatment-related demands imposed by their illness. ${ }^{21}$ Physicians should address barriers to adherence to medical therapy through an open communication between physician and patient.

This study considered many of the important variables related to non-adherence to therapy, however, not all of them could be included. Unfortunately, we could not look for any relationship between non-adherence and disease activity or extent because we adopted a self-administered questionnaire and the patients' perception of disease activity and/or their knowledge of the extent of their disease could be inaccurate. The potential synergistic effect of the presence of other co-morbidities, with particular interest in other chronic diseases, has not also been studied. Future studies should not only include these variables, but also involve other methods to assess adherence. The combination of self-report questionnaires and the administrative data that document prescription refills will allow a more reliable measurement of treatment adherence.

\section{REFERENCES}

1. Haynes RB. Improving patient adherence: state of the art, with a special focus on medication taking for cardiovascular disorders. In: Burke LE, Ockene IS, editors. Compliance in Health Care and research. New York: Futura Publishing Co Inc; 2001. p. 3-21.

2. Rolnick SJ, Pawloski PA, Hedblom BD, Asche SE, Bruzek RJ. Patient characteristics associated with medication adherence. Clin Med Res. 2013;11:54-65.

3. Sewitch MJ, Abrahamowicz M, Barkun A, Bitton A, Wild GE, Cohen A, et al. Patient nonadherence to medication in inflammatory bowel disease. Am J Gastroenterol. 2003;98:1535-44.

4. López-Sanromán A, Bermejo F. Review article: how to control and improve adherence to therapy in inflammatory bowel disease. Aliment Pharmacol Ther. 2006;24:S45-9.

5. Farup PG, Hovde O, Halvorsen FA, Raknerud N, Brodin U. Mesalazine suppositories versus hydrocortisone foam in patients with distal ulcerative colitis. A comparison of the efficacy and practicality of two topical treatment regimens. Scand J Gastroenterol. 1995;30:164-70.

6. Kane S, Huo D, Aikens J, Hanauer S. Medication nonadherence and the outcomes of patients with quiescent ulcerative colitis. Am J Med. 2003;114:39-43.

7. Bassi A, Dodd S, Williamson P, Bodger K. Cost of illness of inflammatory bowel disease in the UK: a single centre retrospective study. Gut. 2004;53:1471-8.

8. Kane SV. Systematic review: adherence issues in the treatment of ulcerative colitis. Aliment Pharmacol Ther. 2006;23:577-85.

9. Kane SV, Cohen RD, Aikens JE, Hanauer SB. Prevalence of nonadherence with maintenance mesalamine in quiescent ulcerative colitis. Am J Gastroenterol. 2001;96:2929-33.

10. Cervený $P$, Bortlík M, Kubena A, Vlcek J, Lakatos PL, Lukás M. Nonadherence in inflammatory bowel disease: results of factor analysis. Inflamm Bowel Dis. 2007;13:1244-49.

11. Rubin G, Hungin AP, Chinn D, Dwarakanath AD, Green L, Bates J. Longterm aminosalicylate therapy is under-used in patients with ulcerative
In summary, we may consider that adherence to therapy in IBD patients is insufficient, and parallels what has been described in other studies. Failure to take medication as prescribed increases the risk that patients will not get the intended benefit, often leading to more frequent relapses and resulting in higher healthcare costs. So, understanding the different patient types, the reasons given by patients for non-adherence, dynamic communication within the healthcare team, educational programs and identifying the predictors of non-adherence, will help devise suitable plans to optimize patient adherence.

\section{CONFLICTS OF INTEREST}

The authors have no competing interests to declare.

\section{FUNDING SOURCES}

This research received no specific grant from any funding agency in the public, commercial, or not for-profit sectors.

colitis: a cross-sectional survey. Aliment Pharmacol Ther. 2002;16:188993.

12. Bernal I, Domènech E, Garcia-Planella E, Marín L, Mañosa M, Navarro $M$, et al. Medication-taking behavior in a cohort of patients with inflammatory bowel disease. Dig Dis Sci. 2006;51:2165-9.

13. Bermejo F, López-San Román A, Algaba A, Guerra I, Valer P, GarcíaGarzón $S$, et al. Factors that modify therapy adherence in patients with inflammatory bowel disease. J Crohns Colitis. 2010;4:422-6.

14. Osterberg L, Blaschke T. Adherence to medication. N Engl J Med. 2005;353:487-97.

15. Robinson A. Review article: improving adherence to medication in patients with inflammatory bowel disease. Aliment Pharmacol Ther. 2008;27:S9-14.

16. D'Incà R, Bertomoro P, Mazzocco K, Vettorato MG, Rumiati R, Sturniolo GC. Risk factors for non-adherence to medication in inflammatory bowel disease patients. Aliment Pharmacol Ther. 2008;27:166-72.

17. Lakatos PL. Prevalence, predictors, and clinical consequences of medical adherence in IBD: how to improve it? World J Gastroenterol. 2009;15:4234-9.

18. Shale MJ, Riley SA. Studies of compliance with delayed release mesalazine therapy in patients with inflammatory bowel disease. Aliment Pharmacol Ther. 2003;18:191-8.

19. Ediger JP, Walker JR, Graff L, Lix L, Clara I, Rawsthorne P, et al. Predictors of medication adherence in inflammatory bowel disease. Am J Gastroenterol. 2007;102:1417-26.

20. Lakatos PL, Czegledi Z, David G, Kispal Z, Kiss LS, Palatka K, et al. Association of adherence to therapy and complementary and alternative medicine use with demographic factors and disease phenotype in patients with inflammatory bowel disease. J Crohns Colitis. 2010;4:28390.

21. World Health Organization. Adherence to long-term therapies: evidence for action; [Consultado 2013 Nov 30]. Disponível em: http://www.emro. who.int/ncd/Publications/adherence_report.pdf. 


\section{Treatment of Inflammatory Bowel Disease: Is your Patient at Risk of Non-Adherence?}

Acta Med Port 2014:27:576-580

Publicado pela Acta Médica Portuguesa, a Revista Científica da Ordem dos Médicos

Av. Almirante Gago Coutinho, 151

1749-084 Lisboa, Portugal.

Tel: +351218428 215

E-mail: submissao@actamedicaportuguesa.com

www.actamedicaportuguesa.com

ISSN:0870-399X | e-ISSN: 1646-0758

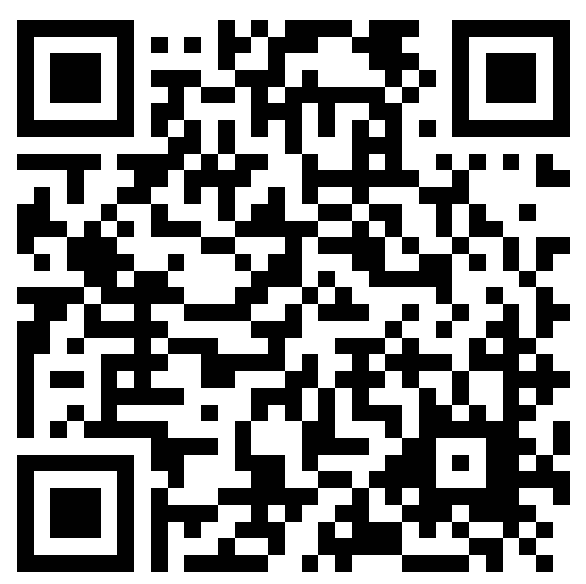

